\title{
The College English Teaching Reform Based on MOOC
}

\author{
Wang Bing ${ }^{1}$ \\ ${ }^{1}$ School of Foreign Language, Leshan Normal University, China \\ Correspondence: Wang Bing, School of Foreign Language, Leshan Normal University, Leshan, Sichuan, China. \\ Tel: 86-135-40551297. E-mail: 23732029@qq.com
}

Received: December 7, 2016 Accepted: January 3, 2017 Online Published: January 5, 2017

doi: 10.5539/elt.v10n2p19

URL: http://dx.doi.org/10.5539/elt.v10n2p19

\begin{abstract}
Nowadays the College English course in China is in the deep blue sea which arouses the deep concerns from all walks of life in the society including the students, teaching experts and the English teachers. Based on the MOOC appearing three years ago, the College English class can be more diverse and beneficial by the means of providing the students with the teaching videos, having the opportunities to discuss the problems with teachers and other students before the class, and finishing the tasks assigned cooperatively with others to further their learning. The College English Reform based on MOOC can be perfected through solving some practical problems that need exploring in the future.
\end{abstract}

Keywords: MOOC, college English, reform

\section{The Introduction}

The concept of MOOC, the abbreviation of Massive Open Online Courses, was first put forward by Dave Cormier, professor of Canadian Edward Prince Island University, and Bryan Alexander, the senior researcher of National Research Institute of Human Education in Canada. In 2012, the MOOC was introduced to the Stanford University, the California University, the Michigan University and the Princeton University, etc. in America. In recent years, the construction and researches of MOOC have become the hot issue home and abroad along with the rapid development in the Internet technology, and many MOOC platforms appear like the mushrooms after the rain such as Coursera, Udacity, Edx, etc. Many leading universities create compile their own MOOC curriculum. MOOC brings about the revolution of the education mode in the digital and information age with its outstanding teaching resources. It becomes the focus of attention among the Chinese reformers in the higher education. As an important and basic subject, the College English course should take full advantage of MOOC to innovate the teaching mode. It is a crucial matter that needs to be studied without any delay.

\section{The Necessity and Practicality of College English Teaching Reform}

\subsection{The Necessity of College English Reform}

As a compulsory course in the college or university, the College English is now in a pretty embarrassing situation. Plenty of colleges set out to cut down the teaching schedule, furthermore some colleges even cancel the College English course. There are many reasons accounting for this. They are listed as follows.

\subsubsection{Students' Lack of Interest in the Course}

With the development of the Internet and multimedia technology and the increase of the transcultural communication, college students have greater demand for the teaching quality than ever because of the deeper exposure to the audio and video English learning materials. Nevertheless due to the lack of teaching facilities and the limitation of the traditional teaching concepts, the input teaching methods still dominate the classroom. In the classroom it is almost impossible for the students to practice their oral English because of the limited teaching time and the scale of the class so that it can't arouse their interest in learning in addition to the dull language material, the abstract language points and the unpopular texts which are completely out of date.

\subsubsection{Large Classes Full of too Many Students}

Large classes are the second reason that results in the poor teaching effect. In this kind of class are usually sixty to seventy students, sometimes the number of whom might approximately add up to one hundred. But their English levels differ from each other with great discrepancy. In most cases, teachers can't cater to their individual need in the English learning. Teachers have no way to carry out the class activities and ensure the 
teaching quality. Apart from it, teachers can't focus their attention on the teaching researches owing to the arduous and high-demanding teaching tasks, which make them worn out and hard to improve the teaching quality.

\subsubsection{The Promotion of Education Equality}

With the rapid development of Internet, anyone can find any information he wants on the Internet with the help of a computer, and the Internet has become the best "class" where the public can have access to the knowledge in concern. They can find the teaching materials of the best quality, which can be better than those any single university can offer. It means too much for the higher education. MOOC best exemplifies this kind of significance, reducing the education cost. Anybody including the college students can take the opportunity to watch the teaching videos, even to communicate with the prestigious professors they've never met through the forums. In contrast to the traditional teaching in the classroom, this kind of instruction is more time-saving, more convenient. Mostly importantly, it enhances the education equality through MOOC with a computer.

\subsection{The Practicality of College English Reforms}

\subsubsection{The Interactive Teaching Mode}

MOOC differs from other online courses in which teachers usually record the teaching procedures in the classroom and post them on the Internet. Thus, the teaching in the classroom is converted into the videos online. Although many students can watch them, the teaching is not different from the traditional classroom teaching in essence. The students watch them without the interaction with teachers, lacking the sense of participation. As for MOOC, in addition to the videos, there are also other contents, such as the test, the exercise and the discussion sections. The learners can understand the difficult parts through watching the video repeatedly. Helps are available through the communication with teachers in the discussion sections. Even you and other students all over the world can become partners during this new kind of learning. The professional teaching teams will explain the common problems the students have met with through the video according to their needs. So MOOC is the combination of teaching, exercises, questions, explanations and discussions. During the course of learning, students can test themselves and finish the exercises teachers have assigned. Meanwhile the server will record it. The feedback will be provided for the administrators to further the improvement of the online courses, which fully represents the interaction between the users and the network by the means of the interactive teaching mode.

\subsubsection{The Realization of the Individual Learning}

It's possible for students to develop the individual learning style in view of the teaching characteristics of MOOC. Students can choose whatever courses he likes regardless of the limitation of time, the place where he stays. The teaching videos in MOOC, different from those traditional online ones, are divided into several short videos in which one or two the teaching points are explained. This kind of teaching takes the individual learning demand into full account and it is a very humane and measure as a result of analyzing the learner's thoughts and taking advantage of the scientific teaching concepts. The short and effective teaching videos can make students learn the course, using their fragmented time and adjust themselves to this kind of learning style.

\section{The Teaching Reform Based on MOOC--The Flipped Class Model}

The flipped classroom describes a reversal of traditional teaching where students gain first exposure to new material outside of class, usually via reading or lecture videos, and then class time is used to do the harder work of assimilating that knowledge through strategies such as problem-solving, discussion or debates

The term flipped classroom is popularized by teachers Aaron Sams and Jon Bergman from Woodland Park High School, Colorado in 2007 in response to a realization that class time would be best spent guiding knowledge and providing feedback rather than delivering direct instruction. Bergman and Sams reason that direct instruction can be delivered by recording video content for students to engage with before class (and any time) freeing up class time for activities that allow deeper exploration of content.

With regard to the definition and the intention of the Flipped Class Model, we can clearly see that MOOC can avail students of the new materials through lecture videos before the class and furthermore it also can trigger the discussion through the online forums, etc. after the class, which is not mentioned above. So it is very crucial to design the teaching procedure online and offline well before and in the class. The teaching online and offline should serve as a whole and should be consistent in the teaching aims.

\subsection{The Teaching Online}

The teaching online before class should pave the way for the teaching offline in class. It serves the purpose of familiarizing the basic knowledge with the students. The online teaching should include three aspects: the 
teaching material, the process and the exercises before class. Before choosing the teaching resources, teachers should have the knowledge of the teaching objectives and the learner's characteristics and then choose or make the MOOC videos. They should not be too long, which will frustrate the students in their learning initiatives. At the same time, it shouldn't be that easy in case the students lose the interest in learning. Before class, students are free to choose where to watch the video depending on their own learning. In the video the teacher can design some quizzes as the passport to the further learning just like the computer games, which can make the students focus on the study. If the students don't master the knowledge, they can review the video. Through the social media and some social APPs such as we-chat, QQ, or other international communication softwares, the students can communicate with the teachers and other learners in their own colleges and from all over the world, sharing the learning experience and having instructive discussions. The teacher can also design some exercises that can trigger the student's thoughts and lead to the discussion in the class.

\subsection{The Teaching Offline}

After the students learn the video materials online, they maybe are not clear about the knowledge in the video, so they come to the classroom with the questions and doubts that need to be answered. Therefore the teacher can adopt the task-based teaching methods to set up some tasks for the students which are relevant to the topic under discussion. The students must cooperate with each other to accomplish the task through team work and the group discussion. Students play a leading role in the learning process by this kind of cooperative and explorative learning style, which can help develop the students' communicative ability, creative and critical thinking . This kind of learning will make students aware of the basic means of scientific research. After the self-leaning before class and the task discussion in class, students can understand the learning contents in some way. The representatives from each group can take turn to have a presentation about their learning. Before the teachers comment on them, the student can evaluate the learning by themselves and put forward some solutions during which the students can understand the learning content even better.

\section{Some Problems to Be Explored}

Although we can improve the College English teaching through the Flipped Classroom Model, a kind of class based on MOOC and the students can play a leading role in their learning process, there are still some problems we need to explore.

\subsection{Textbook-centered or Students-centered}

MOOC can provide the students with plenty of English learning materials through videos, but most of the videos are made according to the English textbooks, including its questions, exercises. The teachers who teach in the videos are not different from those who teach in the classroom in their teaching methods. The students who learn from the video are not so much different from those who learn in the classroom. The major difference is that the former one can learn the material repeatedly while the latter one may miss it if he isn't so concentrated. So in essence the MOOC is still textbook-centered. The student-centered course requires that the teaching should cater to the student's learning need. The teacher should analyze the students- their hobbies, their strong points and weak points in English learning. Some students may be good at oral English, and lack grammar knowledge while others may excel at listening and writing. So the there should provide a variety of videos to meet their needs in one text.

\subsection{Hard to Assess the Learning Effect}

After the students learn the materials, usually they will take a test to show whether he has mastered the knowledge. Here appears the problem. Because the test is taken on the Internet without any supervision, the person who does the test may not be the one who is learning the material. That means the student can ask someone else to do the test for him. So it is not uncommon that the student who is not good at English can get high score in the test. Furthermore, this kind of assessment just applies to the objective questions, such as the multiple choices. It's not suitable for the subjective test, such as the writing. It's hard to evaluate the student's thinking logic because the scoring is more grammatical than structural. So in order to avoid the phenomenon, the peer assessment comes into being which makes the leaner assess each other, but it has its own limitations. First, the students need to master HTML skills which are not easy for everyone. Second, the writer may question the assessment because the score from different assessor many be different, and sometimes there may be great discrepancy depending on the assessor's own English competence. So the score may not really reflect the writer's writing ability.

So we need to carefully think about these two kinds of problems, although the MOOC can actually helps us advance the College English teaching reform through the Flipped Class. The reform can be perfected when we 
solve the problems that leave to be explored and answered for us college English teachers.

\section{Conclusion}

It is urgent that the College English course be reformed in view of the status quo of the teaching practice and benefits the reform based on MOOC can bring about. The key to the success of the reform is to apply the Flipped Class Model, one kind of mode on the basis of MOOC, to the teaching practice reasonably and effectively. So it has become vital to flexibly design the process of the teaching online and the teaching offline and cautiously cope with the relationship between the two parts to the extent that the two parts can serve for each other. That's to say, the former serves as the foundation for the student's learning and discussion in the latter and the latter serves as the consolidation, refinement or sublimation of the knowledge students learn in the former through explorative tasks. Although there are some different opinions about the Flipped Class Model and also it needs to be perfected, I still firmly believe that as long as we can properly handle the key points in the teaching process, the College English reform based on MOOC can and must be successful.

\section{References}

Chen, H. (2014). The Teaching Research of Flipped Class in College English Based on MOOC Resource. HaErbin: Theory Research.

Chen, R. (2016). The Innovation of the College English Teaching Mode in MOOC. HaErbin: Journal of Higher Education.

Gao, D. (2014). A Coolheaded Response to Hot MOOCs: Reflections on the Six Problems of MOOCs. Hangzhou: Journal of Distance Education.

Jordan, R. (1997). English for Academic Purposes: A Guide and Resource Book for Teachers. Cambridge: Cambridge University Press. https://doi.org/10.1017/CBO9780511733062

Liu, X. (2016). The Survey and Application of Blended Learning Model in College English Based on MOOC. HaErbin: Journal of Higher Education.

Stephen, P. B. (2013). Assessing Writing in MOOCs: Automated Essay Scoring and Calibrated Peer Review. Research \& Practice in Assessment.

\section{Copyrights}

Copyright for this article is retained by the author(s), with first publication rights granted to the journal.

This is an open-access article distributed under the terms and conditions of the Creative Commons Attribution license (http://creativecommons.org/licenses/by/4.0/). 